\title{
Phytoremediation Potential of Asopalav (Pollyalthia Lolgifolia) For Degradation of an AZO Dye- Eriochrome Black - T
}

\author{
Chirag Shah ${ }^{1}$, Linz- Buoy George ${ }^{2}$ \\ ${ }^{l}$ Departemt Of Environmental science, School of science, Gujarat University, Ahmedabad, Gujarat. \\ ${ }^{2}$ Department of Zoology, School of science, Gujarat University, Ahmedabad, Gujarat.
}

\begin{abstract}
The use of Phytoremediation is an eco-friendly and non-destructive method of dye removal from water and soil. On the basis of Asopalav ability, is investigated for Phytoremediation. Different experiments were carried out with different concentration of an azo dye Eriochrome black-T (EBT). Degradation of EBT was confirmed with the help of UV-visible spectroscopy. Parameters like $\mathrm{pH}$ and conductivity was also studied before and after treatment with Asopalav (pollyalthia lolgifolia). The values of these parameters were found to be significantly reduced by Asopalav (pollyalthia lolgifolia) within 72 hours and it has been observed that Asopalav is an efficient plant for degradation of dyes from water resources.
\end{abstract}

\section{INTRODUCTION}

Today, more than 100,000 commercial dyes are available in market and nearly one million tonne per annum are produced, whereas $10 \%$ of dyes are released in environment and natural resources as dyestuff waste [1]. This production is increased day by day to meet the needs of growing population, also increases the release of dye effluent. A majority of these dyes are non- biodegradable and toxic to flora and fauna \& even carcinogenic or mutagenic in nature [2]. The textile industry is one of the major sources of dye effluent due to the high quantities of water that are used in the dyeing processes. The effluents from these industries are complex, containing a wide variety of dyes and other products, such as dispersants, acids, bases, salts, detergents, humectants, oxidants, high TDS, sodium, chloride, sulphate, hardness, and carcinogenic dye ingredients [3]. Several physical and chemical methods have been suggested for the treatment of dye-contaminated wastewater but are not widely used because of the high cost, low efficiency, and inapplicability to avoid variety of dyes as well as formation of toxic by-product and secondary pollution that can be generated by excessive use of chemicals [4]. Alternatively, the approach is shifting towards the use of biological methods to treat such waste water containing dyes [5]. These methods are gaining more importance nowadays because of their lesser cost, effectiveness and eco-friendly nature. Phytoremediation is one of such promising non -destructive and eco-friendly technology that uses green plants for contaminants, degradation or extraction of xenobiotics from water or soil. There are several ways by which plants clean up or remediate contaminated sites like Phytoextraction, Rhizofiltration, Phytotransformation, Phytostabilization, and
Phytovolatilization. Phytoextraction is the uptake of contaminants by plant roots and translocation within the plants. Contaminants are generally removed by harvesting the plants. It is the best approach to remove contaminants from soil, sediment and sludge. Rhizofiltration is the use of plants, both terrestrial and aquatic, to absorb and concentrate contaminants from polluted aqueous sources in their roots. Terrestrial plants are more preferred because they have a fibrous and much longer root system, increasing amount of root area that effectively remove the potential toxic metal [6]. Phytotransformation is chemical modification of environmental substances as a direct result of plant metabolism often resulting in their inactivation, degradation (phytodegradation). Phytostabilization is use of plants is to reduce the mobility or bioavailability of pollutants in the environment, thus preventing their migration to groundwater or their entry into food chain. Phytovolatilization is use of plants in the uptake of contaminants from soil and waste water, transforming them into volatilized compound and then transpiring into the atmosphere. A very few studies of phytoremediation have been reported on dye degradation so it is still in experimental stage.Plants of Rheum rabarbarum reported for accumulation of sulfonated anthraquinones dyes. (7) Phragmites australis, a reed which is a component of the wetland community has been extensively studied for remediation of textile effluents and mainly with respect to the removal of the dye, Acid Orange 7 [8]. Typha angustifolia has been shown potential to remediate synthetic reactive dyes waste water treatment [9].Tissue culture and plants of Blumea malcolmii have been found to degrade dyes such as Malachite Green, Red HE8B, Methyl orange, Reactive Red 


\section{Available online at www.ijrat.org}

5B[10,11]. Typhonium flagelliform potentially degrade dye Brilliant Blue $\mathrm{R}$ and textile dye effluent also [12]. Roots of Brassica juncea are able to decolorize methyl orange $92 \%$ within 4 days. (13) Glandularia pulchella efficiently remediate various textile dyes and mixture of synthetic dyes into their nontoxic forms [14-16]. Nopalea cochenillifera (Cactus) transformed various toxic textile dyes including Red HE7B into less toxic and non-hazardous metabolites [17]. Phytoremediation potential of Petunia grandiflora have been explored for disulfonated triphenylmethane textile dye Brilliant Blue $G$ (BBG), dye mixture and textile effluent [18].So, this research work studied the potential of the ASOPALAV (POLLYALTHIA LOLGIFOLIA) (a macroalga, also called as Brittlewort or stonewort) for Phytoremediation against a azo dye Eriochrome Black-T

\section{MATERIAL AND METHODS}

\subsection{Plant Material and extractions:}

Asopalav is commonly found in local area of Ahmedabad. It is actually garden tree. So I used for phytoremediation process. The asopalav (pollyalthia lolgifolia) shoot was collected from Gujarat university campus and in and around Ahmedabad, Gujarat. Samples of plant material were authenticated by the botany department, Gujarat University, Ahmedabad, India. The powder defatted dry plant material (20 gm.) was extracted with $200 \mathrm{ml}$ of solvent for $72 \mathrm{hrs}$., refluxed at a temperature below the solvent boiling point using soxhlet extractor. The crude solvent collected in the flask was concentrated at reduce pressure. The yield collected after drying was kept at $-4^{\circ} \mathrm{C}$ until further use.

\subsection{Chemicals and Dyes}

All chemicals used were of the highest purity available and of analytical grade. Eriochrome black-T (fig 1) was obtained from Merck.

\subsection{Decolourization Experiments}

All decolorization experiments were performed in three sets and average values were determined. First, a screening test was done with Asopalav for Phytoremediation. In screening test, plant (2 g) was suspended in $100 \mathrm{ml}$ EBT solution of $20 \mathrm{mg} / \mathrm{l}$. After 24 hours, plant show very good visible result with accumulation of blue colouration in reproductive parts of plant as well as nodal and intermodal portions. With this indication, further experiments were carried out with different concentration of EBT dye 50,100, 200, $500 \mathrm{mg} / \mathrm{L}$ and control sample to measure the decolourization. Analysis was done by using different analytical methods such as UV/ VIS spectroscopy, $\mathrm{pH}$ metery, conductivity. The supernatant of various dye solutions were analyzed to measure absorbance at their respective absorption maxim $\lambda_{\max }$ (EBT$623 \mathrm{~nm}$ ) using a Systronic-2202 UV-visible double beam spectrophotometer. The $\mathrm{pH}$ of the samples was determined by using a glass electrode $\mathrm{pH}$ meter (E.I.Model111) calibrated at pH 4.0 and 9.0. The conductivity was determined with the help of conductivity-meter.

\subsection{Experimental Setup}

The plants were taken of same growth stage and almost of equivalent dry weights approx. $5 \mathrm{~g}$ (weight taken after keeping the plant on filter paper) for all experiments carried out in 1liter beakers.

Table 1: Experiment Set up

\begin{tabular}{|l|l|}
\hline $\begin{array}{l}\text { Experimental set up (500 } \\
\mathrm{ml})\end{array}$ & $\begin{array}{l}\text { Eriochrome black-T } \\
\text { (EBT) Concentration }\end{array}$ \\
\hline Set a & $50 \mathrm{mg} / \mathrm{L}$ \\
\hline Set b & $100 \mathrm{mg} / \mathrm{L}$ \\
\hline Set c & $200 \mathrm{mg} / \mathrm{L}$ \\
\hline Set d & $500 \mathrm{mg} / \mathrm{L}$ \\
\hline Set-e & Control (without dye) \\
\hline
\end{tabular}

After 72 hours, absorbance of clear solution was measured at respective absorption maxima.

Decolorization percentage was calculated as follows:

Decolorization $\%=$ Initial absorbance-Observed absorbance Initial absorbance $\times 100$

\section{RESULTS AND DISCUSSION}

In this present work, excellent response of Asopalav plant is observed for Phytoremediation of dye waste water. Asopalav is well known for its strong nutrient absorption power. On basis of this ability, it is investigated for Phytoremediation. After $1^{\text {st }}$ day of experimentation, blue-violet pigmentation of reproductive parts start appearing in EBT concentrated water. Blue-violet patches observed in case of EBT concentrated water. This results also points toward strong phytoextraction ability of plant. 


\section{Available online at www.ijrat.org}

Plant show effective decolourization results with both EBT concentrated water. UV-visible spectrophotometric, conductometric and $\mathrm{pH}$ analysis (400-800nm) of different experimental sets were carried out after 72 hours which indicated maximum decolourization in set b (100 mg EBT dye per litre). UV-visible spectra of different sets of EBT concentrated water provide evidence of decolourization. EBT solution of $200 \mathrm{mg}$ per litre showed maximum decolourization percentage $73 \%$ and minimum decolourization occurs in $500 \mathrm{mg} / \mathrm{l}$ dye waste water as shown in figure 3 . In $500 \mathrm{mg} / \mathrm{L}$ EBT concentrated water, plant enzyme became almost law after 1 week and showed only $5 \%$ decolourization. As far as conductivity is concerned, Asopalav decreases the conductivity of different concentration of EBT solution and textile dye waste water. Maximum decreases found in $200 \mathrm{mg} / \mathrm{L}$ EBT concentrated water as shown in figure 4. Also, the results obtained from $\mathrm{pH}$ study of EBT concentrated water gave confirmation about extraction of dyes from the water by plant. After treatment, different EBT concentrated water shows the significant increase in $\mathrm{pH}$ which indicates the concentration of EBT decreased in different solutions to different extent as shown in figure 5. Minimum $\mathrm{pH}$ change observed in $50 \mathrm{mg} / \mathrm{L}$ EBT concentrated water in after 1 week.

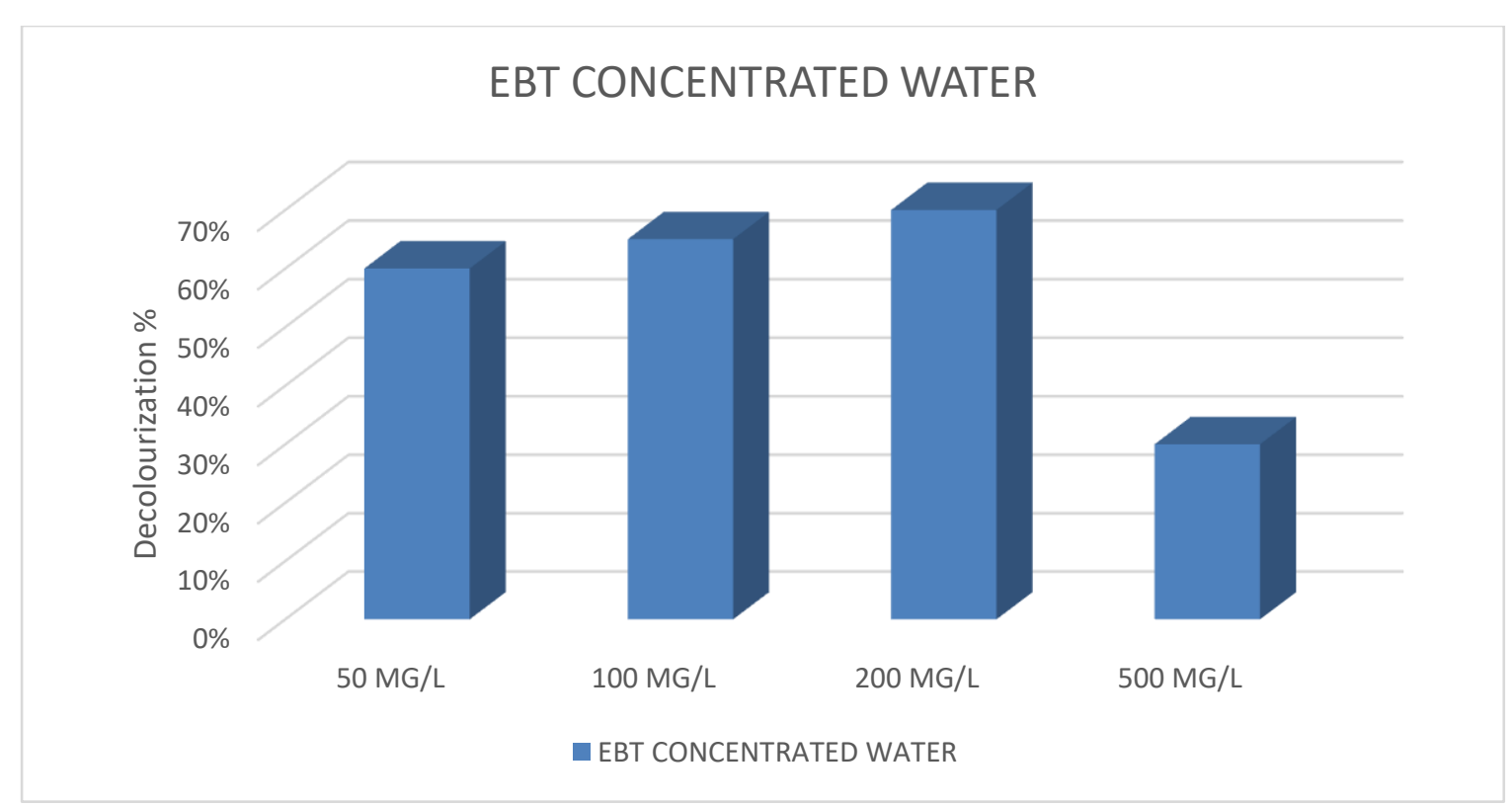

Fig 3. Decolourization \% in EBT concentrated water

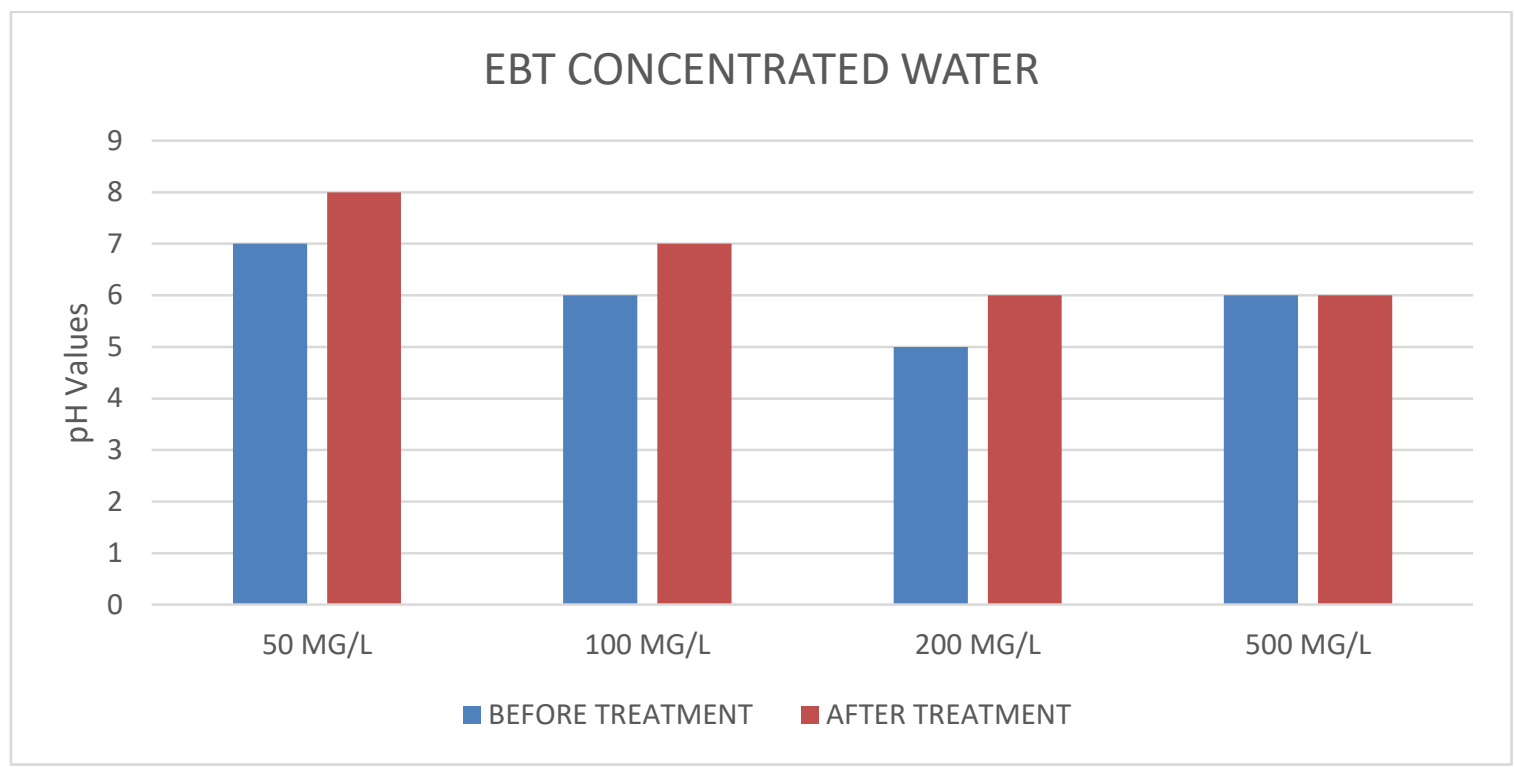

Fig 4. pH Change in EBT Concentrated Water 


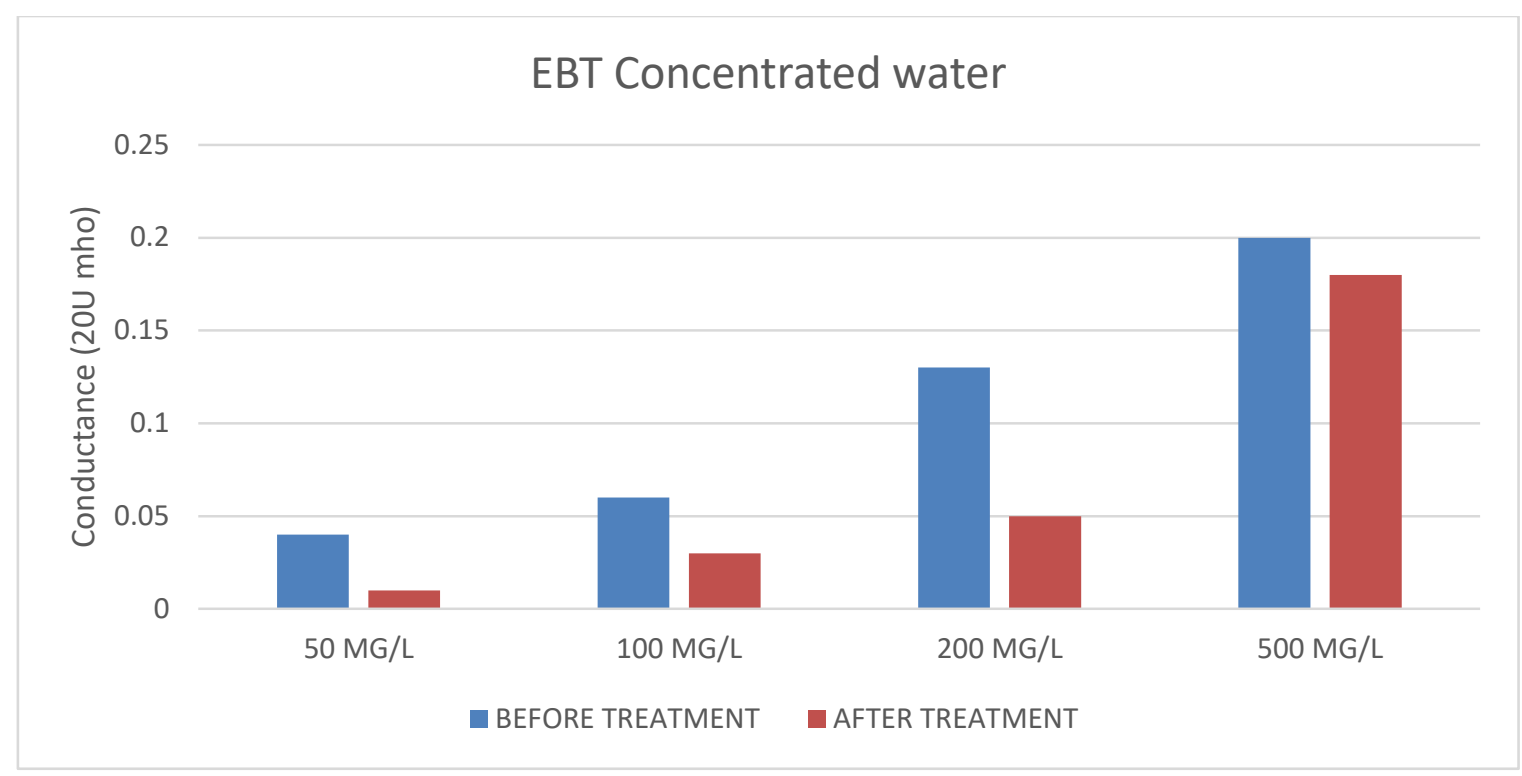

Fig 5. Conductance Change in EBT Concentrated Water

\section{CONCLUSION}

From our study, it was concluded that Asopalav plant has sufficient potential for removing dyes from polluted water. Asopalav plant efficiently removes dyes through phytoextraction process. It extracts dyes from water through its fine rhizoids and stem. Overall, Asopalav plant was found to be most tolerant plant in 70-75\% concentrated water. However, highly concentrated water has negative effect on plant and dye shows its toxic effect on plant. So Asopalav is made more efficient by dilution of waste water.

\section{REFERENCES}

[1] M Ozaki, Y. Adachi, Y. Iwahori, and N. Ishii, Application of fuzzy theory to writer recognition of Chinese asopalavcters, International Journal of Modelling and Simulation, 18(2), 1998, 112-116. (10, Times New Roman) Note that the journal title, in italics

[1] V.K.Garg, R.Kumar and R.Gupta, Removal of malachite green dye from aqueous solution by adsorption using agro industries waste: A case study of Phosphis ceneria. Dyes \& Pigments, A.J.A.S., 62: 10 (2004).

[2]. Hu MR, Chao YP, Zhang GQ, Xue ZH, Qian $\mathrm{S}$ Laccase-mediator system in the decolourization of different types of recalcitrant dyes. J. Ind. Microbiol. Biotechnol. 36:45-51(2009).

[3]. Tchobanoglous, G. and Burton, F.L.,Wastewater Engineering: Treatment, Disposal and Reuse/Metcalf andEddy, New Delhi, India: Tata McGraw-Hill (1995).
[4]. Aubert S, Schwitzguebel JP , Screening of plant species for phytotreatment of wastewater containing sulphonated anthraquinones. Water Qual Res J Can 38:3569-3575(2004)

[5]. Chhotu D. Jadia and M. H. Fulekar, Phytoremediation of heavy metals: Recent techniques. Afr. J. Biotechnol. 8 (6) : 921-928 (2009)

[6]. E. Meers, F. M. G. Tack, S. Van Slycken, A. Ruttens, G. Du Laing, J. Vangronsveld, and M. G. Verloo, Chemically assisted phytoextraction: a review of potential soil amendments for increasing plant uptake of heavy metals. Int. J. of Phytoenergy, 10:390414(2008)

[7] Aubert S.J. and Schwitzguebel J.P., Screening of plant species for the phytotreatment of waste water containing sulphonated anthraquinones, Water Res , 38, 35693575(2004)

[8] Davies L.C., Carias C.C., Novais J.M. and Martins-Dias S., Phytoremediation of textile effluents containing azo dye by using Phragmites australis in a vertical flow constructed intermittent feeding constructed wetland, Ecological Engineering, 25,594-605 (2005)

[9] Nilratnisakorn S., Thiravetyan P. and Nakbanpote W., Synthetic reactive dye wastewater treatment by narrow-leaved cattails (Typha angustifolia Linn.), effects of dye, salinity and metals, Sci Total Environ. 384, 67-76, (2007)

[10] Kabra A.N., Khandare R.V., Kurade M.B. and Govindwar S.P., Phytoremediation of a 
sulphonated azo dye green HE4B by Glandularia pulchella (Sweet) Tronc (Moss Verbena), Environ Sci Pollut Res Int, 18,13601373 (2011)

[11] Kagalkar A.N., Jagtap U.B., Jadhav J.P., Bapat V.A. and Govindwar S.P., Biotechnological strategies for phytoremediation of the sulphonatedazo dye Direct Red 5B using Blumea malcolmii Hook. Bioresour Technol, 100,4104-4110 (2009)

[12] Kagalkar A.N., Jagtap U.B., Jadhav J.P., Govindwar S.P. and Bapat V.A., Studies on phytoremediation potentiality of Typhonium flagelliforme for the degradation of BBR, Planta, 232,271-285,(2010)

[13] Ghodake G.S., Tekle A.A., Jadhav J.P. and Govindwar S.P., Potential of Brassica juncea in order to treat textile effluent contaminated sites, Int J Phytorem, 11, 297-312(2009)

[14] Kabra A.N., Khandare R.V., Waghmode T.R. and Govindwar S.P., Differential fate of metabolism of a sulfonatedazo dye Remazol Orange 3R by plants Aster amellus Linn, Glandularia pulchella (Sweet) Tronc. and their consortium, J Hazard Mater, 190, 424431(2011)

[15] Kabra A.N., Khandare R.V., Waghmode T.R. and Govindwar S.P. , Phytoremediation of Textile Effluent and mixture of structurally different dyes by Glandularia pulchella (Sweet) Tronc, Chemosphere, 87, 265-272 (2012)

[16] Kabra A.N., Khandare R.V., Kurade M.B. and Govindwar S.P. , Synergistic degradation of diazo dye Direct Red 5B by Portulaca grandiflora and Pseudomonas putida, Int $J$ Environ Sci Technol, 10, 1039- 1050 (2013)

[17] Adki V.S., Jadhav J.P. and Bapat V.A., Exploring the phytoremediation potential of cactus (Nopalea Cochenillifera Salm.Dyck.) cell cultures for textile dye degradation, Int $J$ Phytoremed,14, 554-69 (2012)

[18] Watharkar D.A., Khandare R.V., Kamble A.A., Mulla Y.M., Govindwar S.P. and Jadhav J.P., Phytoremediation potential of Petunia grandiflora Juss., an ornamental plant to degrade a disperse, disulfonated triphenylmethane textile dye Brilliant Blue G, Environ Sci Pollut Res Int, 20, 939-949. (2013) 
International Journal of Research in Advent Technology, Vol.6, No.9, September 2018 E-ISSN: 2321-9637

Available online at www.ijrat.org 